Recebido: 20/12/2016

Aprovado: 07/03/2017

\title{
A sombra do liberalismo: Interpretações políticas da obra de Hannah Arendt no Brasil da "virada".
}

\author{
Álvaro Ribeiro Regiani* \\ Kênia Érica Gusmão Medeiros ${ }^{* *}$
}

Resumo: Este artigo visa compreender a recepção da filosofia da história de Hannah Arendt no meio jornalístico na década de 80 no Brasil. Sabe-se que o suplemento Cultura do jornal O Estado de São Paulo, difundia ideias e valores em um formato abrangente, bem como procurava conciliar, através de uma linguagem acessível, um conteúdo com inclinações acadêmicas. Por isso diversos colaboradores, nacionais e internacionais, escreveram artigos, resenhas e colunas destinadas aos mais variados temas sobre história, filosofia e, principalmente, política. A recepção e a resignificação desses temas inferiam um primado, o liberalismo, como estatuto lógico e coerente para o progresso brasileiro. É por meio desta óptica que as ideias e a vida de Hannah Arendt foram colocadas como legitimidade liberal no "Brasil da virada".

Palavras-Chave: Liberalismo; Hannah Arendt; Jornalismo.

Abstract: This article aims to understand the reception of Hannah Arendt's history of philosophy in the journalistic media along the Brazil 80's. Indeed Cultura' supplement of the newspaper O Estado de São Paulo, diffusing ideas and values in a comprehensive format, and sought to reconcile through an accessible language, content with academic aspirations. So many employees, national and international, has wrote articles, reviews and columns designed various topics on history, philosophy, especially politics. The reception and reframing these issues inferred a liberalism primacy, as a logical and coherent status for Brazil's progress. It is through this perception that the ideas and the life of Hannah Arendt were placed as legitimize liberalism in "Brazil's turn".

Keywords: Liberalism; Hannah Arendt; Journalism.

\footnotetext{
* Mestrando em história, programa de pós-graduação em História, Universidade de Brasília. Docente de História da América e da África da Universidade Estadual de Goiás, UEG. alvaroregiani2@ gmail.com

** Doutoranda em história, programa de pós-graduação em História, Universidade Federal de Goiás. Docente de história do Instituto Federal Goiano. keniaerica.gm@gmail.com
} 
No presente momento circulam interpretações, relatos e digressões sobre política em diversos suportes textuais, como jornais impressos, redes sociais e outros espaços de comunicação. O momento é de um acirramento entre posições distintas. Nesse cenário, os veículos de comunicação produzem e reproduzem discursos de acordo com interesses editorais e os preparam para informar públicos específicos. Em tempos em que a noção de pós-verdade é praticada, nesse mesmo contexto, fazem-se necessárias discussões que privilegiem os processos de informação e formação de conceitos e abordagens políticas.

Certas personagens, pelo trágico, pelas ideias ou pela própria vida, tornam-se emblemas da "razão". Seja por suas problematizações aos ideários constituídos ou por corroborarem com permanências e continuidades em diversos cenários sociais. Hannah Arendt é uma dessas personagens. Jornalista, professora e, sobretudo, teórica da vida e das práticas políticas, sua perspectiva intelectual e biográfica ultrapassaram tanto as limites do senso comum quanto as da academia. Desse modo, a autora promoveu diálogos sobre as consequências da participação ou abnegação dos sujeitos em relação à esfera pública. Bem como reforçou a força das ligações entre os eventos históricos de uma época às narrativas produzidas pela historiografia.

Os dilemas apresentados por Hannah Arendt, ainda hoje, são centrais para a compreensão do pensamento político como um meio para diversas interseções e modalidades do conhecimento social. Mundo afora, suas questões foram, polifonicamente, apreendidas como referência liberal, no Brasil isso não seria diferente. Contudo, a unidade do pensamento liberal nunca foi consenso, mesmo sendo articulado por diversos interlocutores como um empreendimento coletivo, não foi necessariamente um "projeto".

Ao analisar este contexto e a recepção das ideias de Hannah Arendt, por meio de uma referência aos discursos de jornalistas, escritores e colaboradores do suplemento "Cultura" do jornal o "Estado de São Paulo", durante a década de 80 no Brasil, podem ser percebidas uma discussão em torno de três eixos: o liberalismo em oposição ao totalitarismo (tanto nazista, quanto stalinista); o progresso liberal como condição natural de oposição ao socialismo científico, revolucionário e latino-americano; e principalmente, a ação política individual em oposição à ideologia das massas.

Em uma aparente "normalidade" democrática jornalistas e colunistas marcavam posição para a passagem segura do regime ditatorial (1964-85) para a Nova República, com publicações sobre a representatividade democrática, a questão autoritária e, sobretudo, a ordem institucional. Bem como advogavam uma oposição a qualquer ruptura violenta do 
poder, tanto pela esquerda quanto pela insurreição das massas. Como demonstrou a colunista Ana Cristina Braga Martes, ao resenhar a obra "Da Violência" de Hannah Arendt no primeiro ano do governo civil pós-autoritário para manifestar uma preocupação com o papel operatório do poder na esfera pública e a violência:

Distinta do poder, a violência passa a ser uma manifestação ideológica, utilizada cada vez mais intensamente, e de maneira equivocada, nas situações de conflito. No entanto, quais seriam as causas para esta expansão vertiginosa deste fenômeno político? Para Hannah Arendt aqueles que recorrem à violência, como forma de oposição ao poder, concebe a história em termos de um progresso inelutável e contínuo, onde apenas a violência seria um dispositivo eficiente para provocar uma interrupção (MARTES, 1986, p. 11).

Interpreta-se nesta passagem, que a ideia de progresso e a sua ruptura violenta assentavam-se como dilemática e, por ser composta por múltiplas opiniões, deveria ser tematizada na ordem política, isto é democrática, sem grandes polarizações ideológicas, tanto de esquerda quanto de direita. No Brasil dos "anos de chumbo" o jornal Estado de São Paulo sussurrou nos ouvidos das elites o que era conveniente para os seus projetos: o medo do populismo e do trabalhismo, ambos identificados como a "República sindicalista". Por consequência, legitimou a violência de Estado como meio para impedir os avanços socialistas, contudo o cenário gradualmente alterava-se, do autoritário para o democrático.

Nos discursos de grande parte da imprensa, o receio do totalitarismo de esquerda e de uma possível falência das democracias liberais persistia no cenário brasileiro, com a passagem "lenta, gradual e segura" do regime militar para o civil. Foi necessário um cuidado especial com o espectro revolucionário, mesmo que o tempo de uma oposição unida pelo comunismo já tivesse passado. Segundo a interpretação do historiador Boris Fausto as esquerdas mantiveram-se juntas enquanto existia um inimigo comum e poderoso, mas, "a medida que o regime autoritário foi se abrindo, as diferenças ideológicas e pessoais começaram a emergir" (FAUSTO, 2002, p. 290).

Com o crescimento do movimento operário, ainda na década de 70 , a representação partidária como o PT (Partido dos trabalhadores) e o PDT (Partido democrático trabalhista), e com a ampliação do número de filiados nos sindicatos, a oposição "marxista" não ganhou popularidade com a possível saída dos últimos generais. As legendas socialistas eram interditadas por lei, mas, mesmo assim a militância do PT superou alguns obstáculos legais e registrou-se ainda na década de 80. Apesar da movimentação de partidos com forte tendência

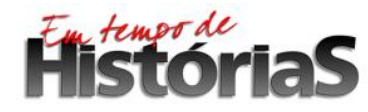


socialista, nesse momento, ainda incipiente e mal organizada, a administração estatal e os meios jornalísticos difundiram uma idealização unitária da esquerda que ameaçava a ordem política.

Mesmo assim, por meio de um suposto "oportunismo", diante da crise econômica durante o governo de José Sarney, a condução das massas pela esquerda poderia romper com o estabelecimento linear dos direitos civis, políticos e democráticos, obtidos com a passagem administrativa dos militares para os civis. A fragilidade política e institucional expunha um medo recorrente, quatro dias antes da publicação da Constituição de 1988, Tereza Maria Sadek referenciava este temor:

Ora, o século XX tem sua fisionomia marcada por guerras e revoluções, que colocaram em xeque a causa básica da política, uma vez que o apelo à violência - traço marcante em ambos os fenômenos - é o contrário da palavra, impõe o silêncio, forçando tudo e a todos a permanecerem em silêncio. A ausência da fala impede o agir conjunto, o exercício da liberdade, instalando-se num espaço sobre o qual a teoria política quase nada tem a dizer. Portanto, sustenta Arendt, "na medida em que a violência desempenha um papel predominante nas guerras e revoluções, elas ocorrem fora do campo político, no sentido estrito, não obstante seu relevante papel na História" (SADEK, 1988, p. 11).

'As revoluções' como 'apelo à violência' poderiam desequilibrar a ordem política ansiada, o que impediria o progresso das instituições democráticas a serem criadas e ou fortalecidas no Brasil. A esfera política deveria ser preservada como elemento positivo diante das instabilidades sociais e econômicas. Em concomitância a reação à esquerda, crescia no meio jornalístico do país. A definição de um modelo de "abertura", no primeiro momento, nos primeiros anos da década de 80 , objetivava assegurar a saída "pacífica" dos generais, por meio de uma aproximação com os ideários liberais e democráticos, para tanto, articularam-se discursos para minimizar os custos políticos e sociais do Regime Militar. Mas, em 1984 a distribuição de concessões aos políticos civis, em detrimento da opressão social, possibilitou a criação de um "pai" e de um "mito fundador" para a democracia. Como sintetizou o professor Celso Lafer em uma resenha sobre livros que narraram a passagem do autoritarismo para a República Nova:

Começo mencionando o livro de Marlyse Meyer e Maria Lúcia Montes: Redescobrindo o Brasil: A festa da política (S. Paulo: T. A. Queiroz, 1985). Este livro procura lidar com dois eventos políticos de forte e inequívoca ressonância popular: (i) a campanha das diretas e (ii) a eleição, doença e 
morte de Tancredo Neves. O grande mérito do livro é procurar desvendar o alcance da participação popular nestes eventos sem incidir no duplo perigo que normalmente caracteriza a discussão sobre o povo: a condescendência elitista e a subserviência ao obreirismo. As autoras partem da noção de festa e da ideia de comunhão que a ela se associa na cultura popular combinando, na sua análise, o código político, o código das letras e o código da fé. Esta interdisciplinaridade é o ponto alto do livro. É em função dela que as autoras iluminam como Tancredo, nas provas e provações, de sua doença, passou a viver como o povo em seu quotidiano, a situação-limite do incompreensível e do insuportável. Daí a ressonância e o alcance popular da morte do grande homem com o qual todos, num momento de comunhão, se identificaram (LAFER, 1984, p. 9).

O mito biográfico, do projeto liberal, só poderia florescer com as expectativas de toda uma nação, assim se reificava uma imagem para Tancredo Neves, o "salvador da pátria". Neste cenário, demarcava-se um antecedente, o autoritarismo, para determinar uma nova ordem para cristalizar uma nova historicidade política. Nessa organização de concessões e ponderações entram o pacto pela anistia (que revogou os crimes do regime) e a redução da culpabilidade dos atentados terroristas ocorridos principalmente durante a linha-dura. A coluna de Celso Lafer queria defender, especialmente, a garantia de expressão midiática para "novas" lideranças e legendas nas arenas públicas brasileiras, se referenciando pelos escritos políticos de Hannah Arendt:

Hannah Arendt ensina que a liberação da necessidade e a contitutio libertatis são dois processos independentes, porém interligados, no sentido de que a autonomia da liberdade numa comunidade política requer que a sociedade não se veja atolada pela questão social. Este é o "leit motiv" da pesquisa, que ao pensar os horizontes da Nova República, dedica-se a examinar como se pode e se devem incorporar à sociedade brasileira as grandes massas marginalizadas - é o tema da igualdade - viabilizando, ao mesmo tempo, as instituições e o processo democrático que ensejam a liberdade. (...) Para que a Nova República não venha a soçobrar no arcaísmo das simplificações, de que são exemplos, o populismo de esquerda e de direita, que não levam em conta a complexidade da realidade que nos cerca (LAFER, 1984, p. 9).

A novidade seria um processo, com a transposição do problema social, a pobreza, e a legitimidade da autonomia comunidade política sem "ismos". A Nova República representava outro começo e, principalmente, a 'continuidade da liberdade'. A recepção e ou leituras desses colunistas sobre a filosofia de Hannah Arendt foram apresentadas a partir de um princípio de continuidade democrático-liberal, mesmos antes ou depois de 1985, com a eleição de Tancredo Neves ou com a Constituinte no governo Sarney, a questão central seria a normalidade política para preservar as instituições.

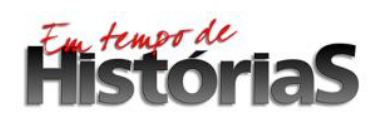

(PPGHIS/UnB) No. 29, Brasília, Ago-Dez 2016 ISSN 2316-1191 
Mesmo que as garantias fundamentais fossem violadas durante o Regime Militar, ou que durante a Nova República a sociedade civil não tivesse ainda uma voz expressiva contra a opressão cotidiana e social. Os militares, as elites políticas e o jornal Estado de São Paulo, não assumiam um cenário autoritário, exceto em alguns períodos, como o fechamento do Congresso e a chamada "remoção do entulho autoritário" com a Constituinte de 1987, por considerarem que a suspensão das garantias individuais e políticas poderiam ser necessárias, além do mais, seriam temporárias e constituiriam como um meio para o progresso brasileiro. O processo de abertura não resultou, necessariamente, em uma efetiva democratização, antes de tudo significou uma alternativa, controlável, de preservação e transição do poder dos militares para as elites políticas sem referendar as questões sociais como observou Boris Fausto,

$\mathrm{O}$ fato de que tenha havido um aparente acordo geral pela democracia, por parte de quase todos os atores políticos, facilitou a continuidade de práticas contrárias a uma verdadeira democracia. Desse modo, o fim do autoritarismo levou o país a uma 'situação democrática' do que a um regime democrático consolidado (FAUSTO, 2001, p. 290).

Interpelar os discursos da mídia impressa no lugar onde são veiculados, sem pretensões de considerá-los fidedignos, sinaliza uma compreensão sobre quais foram os significados atribuídos aos conceitos de democracia, de liberalismo e de autoritarismo neste tempo. A revelia de situar essas matérias jornalísticas ou as práticas políticas como “inexatas", "exóticas", ou mesmo "fora do lugar", como fez Roberto Scharwz certa vez para a literatura (SCHARWZ, 1992, p. 15). Em direção contrária os escritos de Hannah Arendt e as opiniões dos colunistas permitem o trânsito de leituras, traduções e explicações, para assim, apreender, por vias dialógicas, este passado, por meio de suas problematizações.

O suplemento Cultura do Estado de São Paulo, não era redigido, essencialmente por jornalistas, mas por especialistas, nacionais e internacionais, de diversos campos das ciências humanas e literárias. As colunas apresentavam semanalmente discussões em nível acadêmico, por meio de uma linguagem acessível ao grande público, a fim de questionar temas gerais da política brasileira por suas especificidades. Em duas fases distintas, as posições dominantes na elaboração desse caderno podem ser descritas como uma continuidade dos princípios liberais em contraposição a sua plena realização.

A primeira fase pode ser descrita como a defesa do exercício da liberdade de imprensa em um cenário político autoritário; A segunda, apesar da censura já estar instituída, havia 
certo pacto velado entre imprensa e regime, a partir principalmente da década de 80 , com as agitações e pressões pela democracia e com o acirramento de uma crise institucional e econômica. Os grandes veículos de comunicação não mais se interessam por manter qualquer sinal de alinhamento com o governo, passam então a proferir discursos sobre sua própria importância, engajamento e oposicionismo pertinente e moderado. Por outro lado, a incitação de uma abertura liberal-democrática, posicionava-se contra bandeiras radicais e contestatórias.

A rigor, houve três suplementos culturais no jornal Estado de São Paulo, durante os anos autoritários, o primeiro dirigido por Décio de Almeida Prado entre os anos de 1956 a 1966, que em anos subsequentes serviria de modelo para outros cadernos culturais. O segundo de 1966 a 1974 editado por Nilo Scalzo; e o terceiro que se estende da década de 70 até a década de 90. Nas primeiras décadas não havia, aparentemente, um mote político definido, apenas temas sobre os campos artísticos e literários. Nessas primeiras fases os suplementos culturais tentavam aproximar o leitor do universo acadêmico e erudito e, essencialmente, primavam pelas perspectivas do mentor dessa secção, Décio de Almeida Prado:

Semelhante ponto de vista coloca inevitavelmente a questão do nível, da maior ou menor acessibilidade ao leitor comum. Quanto à linguagem, duas observações são necessárias. A primeira é que pretendemos de todos os nossos colaboradores, inclusive os de filosofia e ciências humanas, que fujam ao jargão dos especialistas, atendo-se ao vocabulário de uso corrente, ao alcance de qualquer pessoa bem informada. A segunda é que lhes daremos maior liberdade de linguagem do que gozam habitualmente os redatores desta folha - e isso por várias razões. A língua, ninguém o ignora, é um fenômeno social, uma criação coletiva e anônima, em perpétuo fluxo (LORENZOTTI, 2002, pp. 55-56).

Contudo, a secção passou por duas formatações para adequar-se aos novos moldes informacionais e institucionais. De 1976 a 1980 o "Suplemento Cultural" ainda era gerenciado pelo jornalista Nilo Scalzo. A linguagem dos suplementos "tinha que conter uma parte reflexiva, destinada aos que se interessava por filosofia, literatura, artes, ultrapassando de longe os limites do jornalismo, uma coisa do dia-a-dia" (LORENZOTTI, 2002, p. 81). Quando assumiu a secção em 1981, o jornalista Fernão Lara Mesquista repaginou o suplemento literário, inaugurando o "Cultura", em conformidade com as diretrizes gerais do jornal. A pauta era relacionar o campo literário e artístico com a história, a filosofia, a sociologia e, sobretudo, com a política. 
Por meio de uma fachada da erudição, ocorria uma polarização com o propósito de legitimar um dos lados na dicotomia ideológica que no Brasil pairava, bem como tornar latente qualquer vestígio da associação do periódico ao golpe de 64, sublimando assim um viés de apoio à democracia. Como lembrou André Bonsanto Dias sobre esse momento da política brasileira: “A abertura de uma nova década configura um momento especialmente propício à reflexão. É como se, se pudesse recomeçar tudo do marco zero. Mas, na verdade, o tempo não volta atrás. Por essa razão, tornam-se oportunos os balanços nessas épocas, quando se criam ocasiões novas para se projetar o futuro" (DIAS, 2011, p. 133).

Garantir a continuidade política, mesmo com uma possível mudança de regime seria garantir a nova década. Por isso, a semântica "crise" tinha seu enfoque na defesa do pensamento liberal como condição necessária para repudiar a intervenção de potências internacionais e de suas perspectivas ideológicas para assim inferir o melhor "ismo" para o leitor. Assim, ainda no início da década de 80 quando o Brasil passava pelo fim do "milagre econômico" e amargava a crise do petróleo, o diplomata Marcilio Marques Moreira, escrevia para um futuro próximo:

A esta crise nas sociedades de economia de mercado, situação não menos grave se desenrola no chamado mundo "socialista". Aos problemas gerais próprios ao atual estágio da civilização industrial, a que não estão imunes os dois lados da "Cortina de ferro", vêm a sobrepor-se ali o enrijecimento dos processos políticos e econômicos, o envelhecimento das lideranças, o desfibramento do marxismo como ideologia motora, a falta de arejamento e o resultante esclerosamento da sociedade. Mas, antes de prosseguir na enumeração e análise desse quadro preocupante, caberia perguntar: quais são os elementos básicos que constituem o cerne do liberalismo, que tem sofrido tantos percalços, mas que, em contraste com outros ismos, tem sabido reciclar-se sem sucumbir e continua estandarte esguio - mesmo quando chamuscado - em vez de conformar-se com a condição de verbete do dicionário das ideias ultrapassadas? (MOREIRA, 1981, p. 4).

Marcilio Marques Moreira ao escrever a matéria "Desta árvore pode nascer um Brasil melhor?" confirmava uma das principais premissas do suplemento Cultura na década de 80, evidenciar a contemporaneidade do liberalismo em detrimento do 'ultrapassado' socialismo. A apropriação deste ideário deve ser pensada em seus contextos de uso, bem como, as posições intelectuais que marcaram uma diferença entre os cenários brasileiros e estrangeiros, como analisou Noberto Bobbio, "o liberalismo se manifesta, nos diferentes países em tempos históricos bastantes diversos, conforme seu grau de desenvolvimento; daí ser difícil 
individuar, no plano sincrônico, o momento liberal capaz de unificar histórias diferentes" (BOBBIO, 2000, p. 687).

A defesa do liberalismo como resposta aos desafios do socialismo atendia um objetivo, demonstrar que as soluções dos problemas sociais poderiam estar em sintonia com o progresso político e econômico. O caminho encontrado seria a valorização dos princípios clássicos em somatório com a adequação de novas concepções para novos cenários, sem optar pela institucionalização de um Estado autoritário:

É a tarefa a que se propuseram pesquisadores, estadistas e pensadores. Embora não seja possível dar uma visão aqui de profícuo trabalho -, aliás, ainda incompleto e inconcluso -, a tendência é de dissociar claramente os liberalismos político e econômico das roupagens históricas que assumiram para reconstruir positiva e concretamente as memórias comuns e delinear formas novas adaptadas aos tempos também novos. Há mesmo os que propõem, para que a conclusão entre os dois não persista, divorciar o liberalismo político do liberalismo econômico (sobretudo na medida em que este for concebido como capitalismo selvagem), sem, entretanto jogá-lo nos braços do socialismo, o que seria concubinato espúrio, mesmo que contraído sob o manto de núpcias formais. Em contrário, procurar-se-ia absorver as novas exigências ético-sociais no liberalismo clássico como fez o New Deal, desenvolvendo novas concepções e mecanismos. Do liberalismo econômico tradicional, reter-se-ia o mecanismo de economia de mercado, mas não como caminho único, absoluto. A nova economia social de mercado, ou economia de mercado com responsabilidade social, conviveria com mecanismos reguladores de produção e distribuição dos chamados bens comuns (MOREIRA, 1981, p. 4).

O 'novo' nesta coluna possuía duas acepções, a possibilidade de mudança do estado nacional-desenvolvimentista para o interventor, análogo ao modelo norte-americano. E que a postura ética e social do ideário deveria ser materializada em um projeto político que atendesse as finalidades sociais, sem incorrer nos vícios do paternalismo ou do assistencialismo. Percorrendo um aspecto transformador do nacionalismo ditatorial e da cordialidade nas como se segue:

O veio autoritário que percorre, quase ininterrupto, o curso de nossa história social, não constitui presságio animador quanto às possibilidades de prevalecer entre nós comportamento político liberal. Tivemos governo antes de ter povo, ensina-nos Tristão de Ataíde, e ainda não logramos transformar a estrutura imperial de nossa sociedade em verdadeira nação, adverte Afonso Arinos. Mas, em contrapartida, há traços em nossa tradição, e em nossa psicologia social, que não nos permitem desanimar. Aí estão as afirmações intermitentes do anseio de liberdade, discretas algumas, heroicas outras. Aí estão também a presença do "brasileiro cordial" de Ribeiro Couto, que

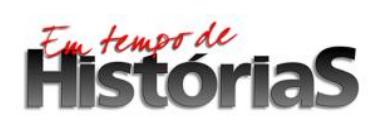

(PPGHIS/UnB) No. 29, Brasília, Ago-Dez 2016 ISSN 2316-1191 
apesar de negado, aflora a todo o momento, preponderando sobre inesperados, e assustadores, surtos de violência (MOREIRA, 1981, p. 4).

O mote da matéria supracitada pode ser compreendido como, a desconstrução de modelos patriarcais na esfera pública, a diminuição da autoridade burocrática na administração governamental e principalmente, a construção de uma cidadania nacionalista e crítica, no sentido de aceitação das contradições da formação da identidade brasileira. Essa se mostrava ainda receptiva para realizar as adequações necessárias para que o Brasil se conformasse um ideal de liberalismo e progresso, atrelado a ideia de modernidade e em oposição ao atraso truculento assentado em terrenos socialistas. Essa liberdade, salvaguardada pelos princípios fundamentais, como a propriedade privada e o direito a vida, só poderia ser alcançada por meio de uma associação a democracia liberal.

O liberal encara a política como estabelecimento de regras de jogo para compor conflitos, mas não exclui - antes pressupõe - a procura de um consenso mínimo. Isto não significa unanimidade, nem conformidade, mas participação efetiva da maioria, legitimamente expressando a sua vontade predominante, e das minorias, defendendo seus pontos de vista que, mesmo sem prevalecer, não deixam de ser respeitado no seio de autêntico pluralismo democrático (MOREIRA, 1981, p. 4).

Para tal construção dessa delimitação que fomentava a necessidade do liberalismo como ideal organizador e pacifista, o suplemento buscou superar o caráter meramente opinativo e informativo, justificando esse posicionamento pelos discursos e citações de uma autoridade intelectual, identificando Hannah Arendt desse modo, como liberal.

Para conhecer o pensamento liberal é preciso recorrer a verdadeiro leque de autores, entre os quais assomam as figuras ínclitas de Locke, Hume, Montesquie, Rousseau, Kant, Adam Smith, Jefferson, Thomas Paine, Guilherme Humboldt, Tocqueville, John Staurd Mill e mais recentemente os já citados Weber, Popper e Arendt, como também Keynes, Ludwig Von Mises, Bertrand Russel, Hayek, Leo Strauss, Carl Friedrich, Dahrendorf, Wittgenstein, John Galbraith, Aron, Karl Deutsch, Robert Noizck, John Rawls (MOREIRA, 1981, p. 3).

Ao filiá-la neste cenário de ideias, em consonância com outros teóricos e pensadores, os promotores da doutrina liberal deveriam clarificar as preocupações políticas em detrimento das econômicas, percebidas na obra da autora. Evidenciar esse aspecto significava uma matriz de legitimação possível para um discurso que carecia parecer bem intencionado e prioritariamente voltado ao incentivo de uma transição política livre das "irresponsabilidades"

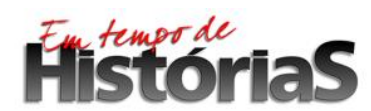


atribuídas ao socialismo, porém, comprometida com o bem-estar de todos. Grosso modo, foi preciso arrancar Hannah Arendt dos contextos de sua produção, despolitizando-a.

Foram às democracias liberais as que no curso deste século tem sabido responder a tamanhos desafios. Pense-se em quem ganhou as duas grandes guerras mundiais, em quem tem melhor combatido o terrorismo sem recorrer ao terror, em que sociedades existem mais equitativa distribuição de renda, em quais delas maior avanço econômico e, mais recentemente, mais efetivo esforço para evitar a poluição ecológica (MOREIRA, 1981, p. 3).

Este “jogo", entre a performance escrita, o conteúdo filosófico e a leitura, produzia um contexto de ambiguidades entre a tradição liberal em oposição ao paternalismo arcaico, bem como apontava um caminho para a sociedade brasileira na ordem "lógico-natural" do liberalismo e da ordem democrática. Este projeto deveria, naturalmente, reivindicar o consenso popular como condição para a governabilidade, respeitando o princípio da responsabilidade cidadã como condição de fomento da cultura política. Por isso, se fazia necessário amparar e afinar os discursos com uma autoridade, no caso Hannah Arendt.

É interessante perceber que, a busca de amparo teórico justamente em Hannah Arendt poderia ter ainda um viés extremamente simbólico. A escritora tinha origem judaica, estudou e escreveu sobre o totalitarismo. Envolveu-se em uma grande polêmica por problematizar e relativizar participações, culpas e demonizações do que acreditava configura-se como a "banalidade do mal". Ou seja, ela poderia ser de algum modo a representação da vítima de um regime totalitário; o exemplo de superação por meio do desenvolvimento de suas próprias capacidades individuais tão caras ao liberalismo; e ainda o modelo de isenção e ponderação de um suposto discurso liberal, tendo em vista que seu trabalho ficou marcado pela já citada problematização de diversos pontos de vista das consequências humanitárias mais graves com a ascensão do totalitarismo alemão.

Não era inédito creditar uma postura liberal para a filosofia desta pensadora que ainda em vida teve por diversas vezes que contradizer alguns interlocutores. Suas posturas contra a esquerda armada, seu fascínio pela independência dos EUA e, principalmente, por suas reflexões para a construção de um espaço público participativo foram alguns dos fatores que a definiram como uma ponte entre o declínio da esfera pública e as reflexões sobre práticas políticas na contemporaneidade. Em outras palavras, seus escritos, convenientemente selecionados, colocavam Hannah Arendt como uma autoridade liberal. 
A autoridade, neste caso apreendida como discursiva, foi empregada pelo jornal, para proporcionar ao leitor uma instância de decisão. Para nortear a consciência dos leitores, por meio de uma linguagem acessível, sobre o reconhecimento imparcial e analítico dos fenômenos políticos. A imparcialidade por sua "verificabilidade imediata", como refletiu Walter Benjamim, designava que o conteúdo das informações possibilitasse ao leitor uma identificação, algo "compreensível em si para si” em um "um ponto de apoio para o que está próximo". Ou como sintetizou o filósofo, "quase nada do que acontece é favorável à narrativa, e quase tudo beneficia a informação" (BENJAMIN, 2012, pp. 218-219).

Segundo a própria definição de Hannah Arendt, a autoridade como princípio, é "uma força pré-argumentativa oposta à coerção, violência e a mera persuasão sendo a veemência que limita a anuência dos atores sociais" (Cf. ARENDT, 2005). Essa tentativa de persuasão do periódico, destacando a autora como autoridade herdeira de uma tradição clássica buscou convencer o leitor do seu direito de fala privilegiado e inquestionável, o que vai contra a própria crença da autora do que se configura uma autoridade. O valor dos autores de renome intelectual foi demonstrado coerentemente com as premissas do jornal, envolvendo o cotidiano do leitor em uma crônica, mas que "no quadro das influências, as setas estão voltadas em todas as direções” (JEANNENEY apud. RÉMOND, 2003, p. 221).

Nos jogos linguísticos, entre a produção e a leitura, a recepção das palavras define-se uma tensão entre a forma e o conteúdo que varia conforme o uso, como observou o historiador Reinhart Koselleck, os conceitos sofrem uma "variação temporal, por isso mesmo histórica, donde seu caráter único articulado ao momento de sua utilização" (KOSELLECK, 1992, p. 138). Por isso, o uso prático dos conceitos filosóficos de Hannah Arendt atendia a fins específicos e sua recepção, mesmo permanecendo lacunar, relacionava-se com os modos de interações com os meios difusores, como aludiu Jesús Martín-Barbero;

O artifício consiste em nos darmos conta de que a verdadeira proposta do processo de comunicação e do meio não está nas mensagens, mas nos modos de interação que o próprio meio - como muitos aparatos que compramos e que trazem consigo seu manual de uso - transmite ao receptor. Sabemos que o consumidor não somente crê, mas é com base nos modos de uso que esses aparatos são socialmente reconhecidos e comercialmente legitimados (SOUZA, 1995, p. 57).

Neste âmbito, a compreensão do vocabulário em um sentido relaciona-se num entre lugar da expectativa e da experiência histórica. Por isso, as matérias jornalísticas queriam demonstrar a verossimilhança com o contexto político, mesmo estabelecendo conexões 
tendenciosas, pretensiosas ou inverídicas, são recobertas no volume, de pensamentos manifestados por grandes pensadores em contextos nem sempre totalmente esclarecidos. Deixam assim vestígios que podem ser, eventualmente, interpretados e narrados, não apenas como ideias de um passado latente, mas como evidências correntes de linguagem política arquitetada com um fim. Tal qual, exposto pelo filósofo do direito Gilberto de Mello Kujawski, em uma matéria intitulada a "Condição Humana"

Cabe indagar, pedindo desculpas pela argumentação ad hominem, na esteira das palavras de Catão, lembradas por H. Arendt: - Quem transformou mais o mundo, Marx com O Capital, ou Descartes que lançou o Cogito como fiat do mundo moderno? Lenin, com sua impetuosa capacidade de ação ou Kant, com a sua silenciosa "revolução copernicana" do pensamento, fazendo-se responsável direto por todas as revoluções importantes a partir do final do século XVIII? Engels ou Rousseau, o promeneur solitaire, que educou sentimentalmente sua geração e todas as gerações posteriores? Catão o disse - o pensador nunca está mais ativo do que quando nada faz (KUJAWSKI, 1983, p. 13).

Ao exagerar na interpretação Kujawski, delimitava a imagem e a filosofia de Hannah Arendt como um contraponto ao marxismo, mas negligenciava a tese central dela sobre o pensamento de Karl Marx. Para Arendt, que procurou compreender os princípios do socialismo a partir de suas máximas, que a rigor definam-se por quatro premissas, "o trabalho criou o homem"; "o homem cria sua humanidade através do trabalho"; "a violência é a parteira da história"; e que "não se pode superar a filosofia sem realizá-la" residia no medo da "nova esquerda", influenciada por um novo padrão de revolução (cubana e chinesa) produzir uma releitura das teses marxistas para legitimar a violência como potência necessária para a implantação do socialismo, como ela ponderou:

A forte retórica marxista da nova esquerda coincide com o firme crescimento da convicção totalmente não marxista, proclamada por Mao Tsé-tung, de que o "poder brota do cano de uma arma". Sem dúvida, Marx estava ciente do papel da violência na história, mas esse papel era para ele secundário; não a violência, mas as contradições inerentes à velha sociedade iriam conduzi-la ao se próprio fim (ARENDT, 2010, p. 26).

O "esvaziamento da política", segundo Hannah Arendt era distante de desenvolvimento fisiológico da história defendido por Karl Marx. Pelo qual a dialética de classes produzia um sentido teleológico da história através das contradições sistêmicas que, eminentemente, levariam a uma revolução. Ao interpretar conceitualmente o marxismo 
Arendt percebeu que o papel da violência era secundário em sua obra, apenas um sintoma do agravamento das contradições dos meios de produção. Um resultado aparente da filosofia marxista foi condicionar a humanidade, sua victa activa, ao essencialismo da produção, reduzindo outras atividades da condição humana e elevando o labor como imperativo para a humanidade. O homo faber para Marx, não era a essência humana, mas o efeito do movimento da economia-histórica que condicionava as ações humanas, criando-as.

Para a autora ocorria uma distinção essencial entre as duas categorias, labor e trabalho. O labor é definido como o ciclo vital da humanidade, a condição própria da vida. A função desta etapa é satisfazer as necessidades básicas dos seres humanos, contudo esta atividade não deixa nenhum registro memorável ou durável, uma vez que ao suprir as necessidades os resultados desaparecem. Uma vez que o que Marx chamou de trabalho, ela o definiu como labor, sendo "a atividade que corresponde ao processo biológico do corpo humano, cujo crescimento espontâneo, metabolismo e eventual declínio têm a ver com as necessidades vitais produzidas e introduzidas pelo labor no processo da vida" (ARENDT, 2007, p. 15).

Em contrapartida, o trabalho corresponde ao não-natural, "ao artificialismo da existência humana, existência esta não necessariamente contida no eterno ciclo vital da espécie, e cuja mortalidade não é compensada por este último" (ARENDT, 2007, p. 15). Esta última atividade corresponde à ocupação dos homens na terra, permitindo nos espaços criados por eles a continuidade da vida social, a "mundanidade", pois "o trabalho (labor) era para ele [Marx] a reprodução da vida do próprio individuo, que lhe assegurava a sobrevivência, enquanto a procriação era a produção de vida alheia, que assegurava a sobrevivência da espécie" (ARENDT, 2007, p. 118).

Ao distinguir a singularidade dessas duas atividades Hannah Arendt ansiava tornar inteligível para seus contemporâneos, o que para a era moderna pareceu ser uma confusão teórica. Em especial nas ideias de Marx, o trabalho e o labor apresentavam-se como homogêneos e em alguns casos, na profundidade de seu pensamento, não havia qualquer distinção conceitual. Algo não relacionado na matéria de Gilberto de Mello Kujawski, que ao criticar a sociedade de massas, instrumentaliza o homo laborans como as massas ideologicamente amorfas do socialismo e o homo faber como liberais, proponentes do progresso:

O animal laborans é ainda servo da natureza e da Terra; só o homo faber se porta como amo e senhor de toda a Terra, porque é senhor de si mesmo e de seus atos. Na medida em que é homo faber instrumentaliza todas as coisas à categoria de meios e acarreta a perda de seu valor intrínseco e independente,

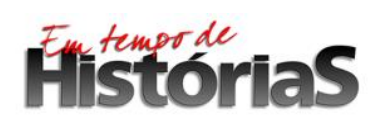


até mesmo da terra e da natureza. (...) Os artistas, os poetas, os historiógrafos, os escritores representam o homo faber em suas categoria mais alta, autores de obras de suma permanência, necessários para que sobrevivam os feitos realizados pelos homens que agem e falam, isto é os homens de ação (KUJAWSKI, 1983, p.13).

Os 'homens de ação', liberais, tinham por missão batalhar por ideais sem ser, ideologicamente, comprometidos com a sua sociedade, mas mantendo uma ordem sociável. O homo faber em oposição ao homo laborans, por sua instrumentalidade, surgia da contradição entre a natureza e a produção, ou seja, do domínio da natureza pela utilização das ferramentas por ele criada. A crítica filosófica de Hannah Arendt servia para uma contraposição da sociedade massificada ao ponto de burocratizar o pensar. Contudo, esta tese, apropriada pelo colunista do Estado de São Paulo, servia para diagnosticar as massas operárias homogeneizadas, definida nos seguintes termos:

No labor o produto do trabalho destina-se ao consumo; no trabalho, ao uso. A moderna sociedade consumista transforma o trabalho livre em labor. Vivemos hoje numa sociedade de operários ("Laborers"), ou seja, de homens que "laboram", na qual os produtos são consumidos com velocidade crescente. Ao inverso do que esperava Marx, as horas vagas conquistadas pelo animal laborans não são empregadas em transformá-lo num superiormente produtivo (KUJAWSKI, 1983, pp. 12-13).

Por meio de apropriações conceituais esses jornalistas atribuíram uma certeza racional das leis universais e naturais, um sentido lógico e dedutivo para a emancipação da espécie humana, o progresso antes de 1985. Contudo, após a passagem do regime autoritário para o civil ocorreu uma crescente suspeita em relação aos projetos vencedores da Segunda Guerra Mundial, em especial o Comunismo de Estado na Rússia, o New Deal nos Estados Unidos e o nacional-desenvolvimentismo na América latina que tornaram-se alvos de críticas por seus grandes enunciados. Todos, atrelados a ideia de progresso, ora como transformação do "homem velho em novo" ou do "desenvolvimento" ora como o "motor da história".

O Brasil da "virada" não estaria distante dessa discussão, a disputa política e econômica pela "evolução social” era uma questão central nas querelas ideológicas. Por isso, ao resenhar o livro "História da ideia de progresso" de Robert Nisbet em 1986 Gilberto de Mello Kujawski vincula o fluxo continuo da história a três instâncias que culminam com o avanço do liberalismo, sendo esta a única possibilidade lógica para a emancipação humana, assim: "Os três pressupostos condicionantes da ideia de progresso, devido ao Cristianismo: o sujeito do progresso (a humanidade); o argumento do progresso (a transformação, por etapas 
ascendentes, do homem velho no homem novo); e a dimensão do progresso (o tempo da promessa, retilíneo e não circular)" (KUJAWSKI, 1986, p. 5).

O progresso "como não é só uma ideia triunfante e identificada como lei natural" (KUJAWSKI, 1986, p. 5) foi uma tendência histórica, oriunda do humanismo, do cientificismo e, em especial, do iluminismo, surgindo, apenas, no Ocidente e representado pelo liberalismo. $\mathrm{O}$ progresso pertencia à modernidade racional europeia em um cenário que o permitiu nascer, por isso, ao posicionar uma premissa, a partir da filosofia de Hannah Arendt, o colunista negava categoricamente "algo como o progresso da Humanidade (tivesse existido) antes do século XVII" (KUJAWSKI, 1986, p. 5). Por isso, o curso natural da história seria o liberalismo ao contrário do ramo socialista que desembocaria na involução da humanidade.

Esta ideia como exposta na coluna do jornal naturalizava as ações e a causalidade humanas a um processo teleológico e singular pelo qual as cronologias estabeleciam condições e limites para as ações futuras. Contudo, novamente os aspectos negligenciados pelo colunista poderiam cingir sua interpretação exposta na coluna. A mecânica linear do tempo foi para Hannah Arendt um modelo de reificação metafísica para a nulificação dos aspectos contingências, próprios da ação humana, e apresentou-se como um dos principais riscos para a compreensão da condição política e da história.

O "tempo manipulável" e "mecânico", duramente recriminado por Hannah Arendt em vida, não foi abordado pelo colunista. Em contramão, para Gilberto de Mello Kujawski o progresso "em qualquer ponto que tomemos o homem em seu percurso histórico, ele está sempre situado em certo nível cultural, social, tecnológico, político, erigido pelo trabalho dos seus antepassados" (KUJAWSKI, 1986, p. 5). Neste âmbito, e ainda lançando as ideias do colaborador do jornal, a "evolução social” constituiu uma relação entre teorias da história com a política, a fim de criar um binômio entre formas de progresso liberais em oposição à socialista como disputa democrática, pois "está cada vez mais dividia entre a democracia liberal e o socialismo" (KUJAWSKI, 1986, p. 5).

Este comentário buscava uma explicação, aparentemente, oculta do grande público para introduzir enunciados correntes, assim autorizava uma opinião, por sua validação lógica, em um meio informativo que repetia uma ideia para, prontamente, enquadrá-la como tradição:

O que significa progresso para uns, encarna para outros o mais terrível retrocesso. Com a perda da concórdia e a civilização ocidental anarquizada pela guerra civil, o progresso perdeu o seu abstrato e degenerou em termo essencialmente equívoco, inservível para aquela ampla mobilização, sem

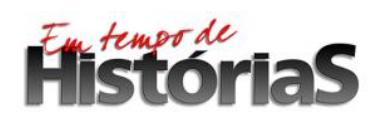

(PPGHIS/UnB) No. 29, Brasília, Ago-Dez 2016 ISSN 2316-1191 
distinções de classes, nações ou ideologias, como foi nos séculos anteriores. Politicamente, o termo "progressista" tornou-se distintivo do progresso tal como a esquerda gosta, o que caracteriza a apropriação ilegítima e abusiva do termo, portanto a ideia de progresso exprime movimento para a frente, e não para a esquerda ou direita (KUJAWSKI, 1986, p. 5).

Esta aparente contradição lógica entre a exposição de Kujawski e a perspectiva de Hannah Arendt residiria na refutação do progresso e na crença que a "obediência cadavérica" a uma "lei histórica" possibilitou homens como Adolf Eichmann o poder de organizar e coordenar o genocídio de milhares de judeus. O "dever" que produziu a morte de milhões pela burocracia foi por ela definida como "banalidade do mal". Essa crítica a noção processual da história permitiu observar que as opiniões dos colunistas nem sempre estavam alinhadas a um eixo normativo do jornal, em contraposição a Kujawski, ainda em 1983, Alfred Kazin, em um texto traduzido do N. Y. Review of Books, com o título "Hannah Arendt: O amor e a solidão", redigia as seguintes palavras:

A tese da "banalidade do mal" foi consequência da ideia, agora favorita de Hannah, de que meros burocratas, funcionários terrivelmente "comuns" como Eichmann, não "pensavam" naquilo que faziam e eram tediosos para o gosto da filósofa. (...) A própria Hannah desaprovou a tese da banalidade quando no inicio do livro critica a tentativa do promotor de explicar os atos de Eichamann pela sua personalidade diabólica. Como ela disse o réu, especialmente num julgamento por crime, deve ser julgado não pela sua "personalidade", mas por seus atos (KAZIN, 1983, p. 4).

Afinal, "não há nenhuma banalidade na "exterminação" (como o mundo veio a chamar) de seis milhões de judeus" (KAZIN, 1983, p. 4). A novidade radical, o totalitarismo, ergueu a destituição do espaço público pela massificação da sociedade, justificada por uma "lei histórica" por uma instrumentalização da violência sob o signo da burocracia, constitui o sentido negativo das revoluções, o espaço do isolamento do "eu" em sociedade. Essa foi uma possível interpretação dentre muitas, mas é com certeza a mais conveniente. A banalidade do mal em Hannah Arendt não se encerra na personalidade de Eichaman, essa é quase uma metáfora para uma situação muito maior. A divisão rígida do trabalho no sistema nazista fazia com que o sujeito partícipe, perdesse a compreensão holística do empreendimento e permanecesse atenta a banalidade de sua função específica. A linha de produção nazista dividiu e burocratizou atividades, utilizando para isso da lógica e do tempo mecânico, fabril e destituidor da autonomia de pensamento. 
As críticas de Hannah Arendt a tese do "dente da engrenagem", a levou a ficar escandalizada com a incapacidade do não pensamento durante o regime nazista. Que por si só seria definida como o isolamento do indivíduo com sua identidade ou com conciliação histórica, conforme foi apresentado, muito tempo antes dos artigos de Kujawski e de Kazin em 1981, por outro colunista do jornal, Richard Rubinstein:

Sua conclusão foi que "o terror só pode ter domínio absoluto sobre os homens e mulheres que estejam isolados um contra o outro". O isolamento a que Hannah Arendt se refere é diferente do isolamento auto-imposto pelo artesão ou o artista, que contribuiu fundamentalmente para a criação do mundo comum. O isolamento que constitui a precondição do terror totalitário no período moderno é a solidão e a extirpação dos homens e mulheres supérfluos (RUBINSTEIN, 1981, p. 4).

Logo, qualquer revolução poderia incorrer no risco de cair neste abismo, mas o que subjaz do progresso liberal ou da condução socialista seria o continuum histórico e a negação da contingência na esfera pública e na história. Em 1986, como induziu Hayden White, em um artigo para o suplemento Cultura, também traduzido do N. Y. Review of Books, posiciona Hannah Arendt como crítica da noção processual da história, mas como liberal, "como resultado do trabalho de Karl Popper, Karl Loweth, Hannah Arendt e muitos outros liberais e humanitaristas que vinculavam a fé na História ao totalitarismo numa relação de causa e efeito" (WHITE, 1986, p. 12).

As contradições internas no próprio jornal, pela exposição de diversas perspectivas, indicam as divergências ideológicas e teóricas que o Brasil vivia durante a década de 80. As perdas das certezas utópicas ou ideológicas demonstram a superfície do que jornalistas e intelectuais definiam como crise. Mas, a defesa do liberalismo e da democracia representaria algo diferente, no mínimo, segundo suas expectativas, algo inovador.

O liberalismo democrático como afirmação política nesse jornal tinha um caráter pragmático por seus princípios, mas apresentava limites. A situação autoritária, conveniente aos padrões do editorial, bem como de apropriações da filosofia da história de Hannah Arendt demonstraram, entre certezas e incertezas, uma apreensão das categorias e conceitos de um tempo vivido. Por meio desses textos que os fundamentos intelectuais e seus horizontes podem ser compreendidos. O caráter de qualquer narrativa consiste em produzir explicações, construções de ideias, conceitos e sentidos; bem como o seu inverso: contradições, falácias e mentiras. Ou seja, essa atividade adquire um significado quando articulada a vivência e a um contexto e, ambas, localizadas em uma experiência temporal. 
Por isso quando se apropriaram de questões do pensamento político e a transmitiram para o grande público indicaram, possíveis sentidos em que o liberalismo, a democracia e, sobretudo, a ordem política deveriam caminhar na década de 1980. Sabe-se que o tecido social é perpassado por uma infinidade de emoções, contradições, decisões e discursos, cobertos pela poeira rotineira de edições, bem como que projetos são tão importantes quanto experiências históricas. O que aproximava em alguns casos, mas também distanciava da abordagem de Hannah Arendt, em uma coreografia, demasiadamente, ensaiada.

Quando Hannah Arendt propôs uma antinomia no conceito de história, e subsequentemente, no de revolução, relativizou as noções de autoridade, progresso, revolução e o uso violência como possibilidade de construção para a vida pública para que seus leitores pudessem pensar por si mesmos. A aproximação de sua filosofia com o liberalismo parece difusa, contudo isso não encobre suas fundamentações. Um dos grandes objetivos da autora era compreender a mudaneidade de forma a abarcar a pluralidade das ações humanas, mesmo não concordando com parte, essencial, delas. Como comentou Karin A.Fry, "Hannah Arendt começou uma conversa, e agora cabe a nós continuá-la” (FRY, 2010, p. 20).

\section{Referências Bibliográficas}

ARENDT, Hannah. A condição humana. Rio de Janeiro: Forense Universitária, 2007.

. Entre o passado e o futuro. São Paulo: Perspectiva, 2005.

. Sobre a violência. Rio de Janeiro: Civilização brasileira, 2010.

KAZIN, Alfred. Hannah Arendt: O amor e a solidão. Estado de São Paulo, São Paulo, 11. Set. 1983. Ano IV. Suplemento Cultura.

KUJAWSKI, Gilberto de Mello. A condição humana. Estado de São Paulo, São Paulo, 16 jan. 1983. Ano II. Suplemento Cultura.

Suplemento Cultura. . A ideia de progresso. Estado de São Paulo, São Paulo, 18 Out. 1986. Ano IV.

LAFER, Celso. O Brasil em discussão. Estado de São Paulo, São Paulo, 22 Dez. 1985. Ano V. Suplemento Cultura.

MARTES, Ana Cristina Braga. Da violência. Estado de São Paulo, São Paulo, 12 set. 1986. Ano VI. Suplemento Cultura.

MOREIRA, Marcílio Marques. Desta árvore pode nascer um Brasil melhor? Estado de São Paulo, São Paulo, 22 mar. 1981. Ano I. Suplemento Cultura

RUBINSTEIN, Richard. Sobre o totalitarismo. Estado de São Paulo, São Paulo, 22 nov. 1981. Ano II. Suplemento Cultura.

SADEK, Maria Tereza. Da revolução: O resgate do espírito revolucionário. Estado de São Paulo, São Paulo, 01 Out. 1988. Ano VII. Suplemento Cultura.

WHITE, Hayden. Do fé ao fatalismo. Estado de São Paulo, São Paulo, 2. Fev. 1986. Ano V. Suplemento Cultura.

BARTHES, Roland. O rumor da língua. Brasília: Editora Brasiliense, 1988.

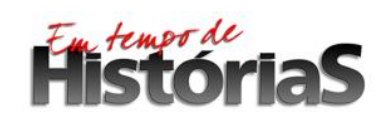


BENJAMIN, Walter. Magia e técnica. Ensaios sobre literatura e história da cultura. São Paulo: Brasiliense, 2012 BOBBIO, Noberto (org). Dicionário de Política. Brasília: Editora Universidade de Brasília: São Paulo: Imprensa Oficial do Estado de São Paulo, 2000.

DIAS, André Bonsanto, As memórias da Folha de S. Paulo durante o regime militar no Brasil: O processo de construção de uma identidade a partir de suas lembranças e esquecimentos. Revista Estudos em Comunicação [Comunication Studies], Beira: Portugal, n. 2. Dec. 2011. Disponível em: <http://www.ec.ubi.pt/ec/10/pdf/EC10-2011Dez.pdf>. Acessado em: 4 mar. 2016.

FAUSTO, Boris. História concisa do Brasil. São Paulo: Editora da Universidade de São Paulo, Imprensa Oficial do Estado, 2002.

FRY, Karina A. Compreender Hannah Arendt. Petrópolis: RJ: Editora Vozes, 2010.

KOSELLECK, Reinhart. Uma história dos conceitos: Problemas teóricos e práticos. Estudos históricos. Teoria e história Rio de Janeiro, 1992, vol 5, n. 10.

LORENZOTTI, Elizabeth de Sousa. Do artístico ao jornalístico: vida e morte de um suplemento; Suplemento literário de O Estado de São Paulo (1956 - 1974). São Paulo: USP, 2002. Dissertação (Mestrado em jornalismo) - Escola de comunicação e artes da Universidade de São Paulo.

RÉMOND, René (Dir.). Por uma história política. Tradução Dora Rocha. $2^{\mathrm{a}}$ Ed. Rio de Janeiro: Editora FGV, 2003.

SOUZA, Mauro Wilson de (Org.). Sujeito: O lado oculto do receptor. Tradução e transcrição Sílvia Cristina Dotta e Kiel Pimenta. São Paulo: Brasiliense, 1995.

SCHARWZ, Roberto. Ao vencedor as batatas. São Paulo: Duas Cidades, 1992. 